\title{
Ozone and volatile organic compounds in the metropolitan area of Lima-Callao, Peru
}

\author{
José S. Silva ${ }^{1} \cdot$ Jhojan P. Rojas ${ }^{1} \cdot$ Magdalena Norabuena $^{1} \cdot$ Rodrigo J. Seguel $^{2}$ (D) \\ Received: 9 May 2018 / Accepted: 12 July 2018 / Published online: 26 July 2018 \\ (C) Springer Nature B.V. 2018
}

\begin{abstract}
This study analyzes ozone formation in the metropolitan area of Lima-Callao as a function of meteorological patterns and the concentrations of nitrogen oxides and reactive organic gases. The study area is located on the west coast of South America $\left(12^{\circ} \mathrm{S}\right)$ in an upwelling region that is markedly affected by the Southeast Pacific anticyclone. The vertical stability and diurnal evolution of the mixing layer were analyzed from radiosondes launched daily during 1992-2014 and from two intensive campaigns in 2009. Vertical profiles show that during June-November, the subsidence inversion base ranges from 0.6 to $0.9 \mathrm{~km}$ above sea level (asl). In contrast, during December-May, subsidence inversion dissipates, leading to weak surface inversions from 0.1 to $0.6 \mathrm{~km}$ asl. At the surface level, compliance with the ozone standard of 51 parts per billion by volume (ppbv) is explained by the marine boundary layer effect and by strong inhibition of ozone formation due to titration with nitric oxide. Day-of-the-week variations in ozone and nitrogen oxides suggest a VOC-limited ozone-formation regime in the atmosphere of Lima. Furthermore, the pattern of $\mathrm{C}_{6}-\mathrm{C}_{12}$ species indicates that gasoline-powered vehicles are the main source of volatile organic compounds (VOCs), whereas the species with the greatest ozone-forming potential corresponded to the sum of the isomers m- and p-xylene. Mean benzene concentrations exceeded the standard of $0.63 \mathrm{ppbv}$, reaching $1.2 \mathrm{ppbv}$ east of Lima. Nevertheless, the cancer risk associated with the inhalation of benzene was deemed acceptable, according to USEPA and WHO criteria.
\end{abstract}

Keywords Tropospheric ozone $\cdot$ Volatile organic compounds $\cdot$ Benzene $\cdot$ Marine boundary layer $\cdot$ Radiosonde

\section{Introduction}

Tropospheric ozone $\left(\mathrm{O}_{3}\right)$ and volatile organic compounds (VOCs) are key components in atmospheric chemistry. At the surface level, ozone is considered one of the main anthropogenic atmospheric pollutants (Schultz et al. 2017). Furthermore, ozone is a key greenhouse gas due to its strong absorption in bands of terrestrial infrared radiation (Monks et al. 2015).

$\mathrm{O}_{3}$ is a secondary gas formed through photochemical oxidation of VOCs in the presence of nitrogen oxides $(\mathrm{NO}+$

Rodrigo J. Seguel

roseguel@icloud.com

José S. Silva

jsilvacotrina@gmail.com

1 National Meteorology and Hydrology Service, Jr. Cahuide 785, Jesús María, Lima, Peru

2 Environmental Department, Trade and International Advisory SAGU, Los Canteros 8666, Parque industrial de La Reina, 7880340 Santiago, Chile
$\mathrm{NO}_{2}$ ), which are known as precursors (Fiore et al. 2015; Alvim et al. 2017; Toro et al. 2013, 2014). Therefore, environmental agencies commonly assess VOCs in ozone nonattainment areas. The US Environmental Protection Agency (USEPA) updated the list of 54 target VOCs measured at photochemical assessment monitoring stations (known as 54 PAMS) and currently recommends monitoring 25 organic species that are mainly prioritized according to their contribution to ozone formation (USEPA 2017). Other criteria include the role played as secondary organic aerosol precursors, and whether the compounds are considered hazardous air pollutants.

In urban areas, large proportions of organic precursors derive from mobile sources (Fujita et al. 2012; Seguel et al. 2012; Rappengluck et al. 2005). Biogenic VOC emissions derived from vegetation may also contribute to the inventory of $\mathrm{O}_{3}$ precursors (Chameides et al. 1988). Apart from photochemical ozone formation, stratosphere-troposphere exchange favors irreversible ozone transport from the stratosphere and is thus another source of ozone, particularly for the upper and middle troposphere (Seguel et al. 2018).

Epidemiological studies have shown significant associations between contamination by $\mathrm{O}_{3}$ and damage to human 
health (Bell et al. 2004; Liu and Peng 2018). The most important effects are decreased lung function, respiratory tract inflammation, pharyngeal irritation, functional changes, and asthma symptoms in susceptible people (Lippmann 1991). Forouzanfar et al. (2015) estimated the number of deaths attributable to ozone exposure in 2013 at 217,000, which is $63 \%$ higher than in 1990.

Due to the adverse health effects of ozone, many agencies have established air quality standards following World Health Organization (WHO) guidelines, which set a value of $51 \mathrm{ppbv}$ for ozone. Accordingly, Peru has stringent standards of $51 \mathrm{ppbv}$ for ozone and $0.63 \mathrm{ppbv}$ for benzene (MINAM 2017). The latter is not only a key organic ozone precursor but is also a known carcinogen (ATSDR 2007).

In Peru, in 2010, the first Automatic Air Quality Monitoring Network, the so-called RAMCA (for its acronym in Spanish), was implemented in the Metropolitan Area of Lima-Callao (MALC), comprising 10 stations that record hourly concentrations of gases and atmospheric aerosols (Silva et al. 2017) over a vast geographical area with complex terrain. The network is currently operated by the National Service of Meteorology and Hydrology (SENAMHI) under the Ministry of the Environment (MINAM).

Air quality in Lima is largely modulated by a persistent weather and climate pattern (Enfield 1981). Underhill (2015) determined that higher $\mathrm{NO}_{2}$ concentrations are found during the warm period than during the cold period. In turn, $\mathrm{CO}$ records and the prevailing wind show that polluted air masses are transported to the northeast of the city (Tashiro and Taniyama 2002).

Despite recent efforts, characterization of Lima's photochemical pollution is scarce in the scientific literature, and the lack of permanent VOC measurements is a key information gap that must be bridged to properly address their management and to determine the population's exposure to hazardous organic species. Therefore, the objective of this study is to relate meteorological patterns to air quality in the Lima-Callao metropolitan area, and to identify the atmospheric chemical processes that govern the ozone formation regime in the city. To meet these objectives, atmospheric stability is first analyzed from 23 years of radiosondes that were launched between 1992 and 2014, followed by diurnal characterization of the marine boundary layer during summer (February) and winter (August) 2009. Subsequently, ozone behavior is analyzed as a function of precursors of $\mathrm{NO}_{\mathrm{x}}(\mathrm{NO}+$ $\mathrm{NO}_{2}$ ) and reactive volatile organic compounds in periods and regions of interest. Finally, the levels of reactive organic gases are contextualized, prioritized in terms of their potential contribution to ozone formation, and compared with national standards and international guidelines.

\section{Methodology}

\section{Study area}

The MALC is located on the west coast of South America $\left(12.0^{\circ} \mathrm{S}, 77.0^{\circ} \mathrm{W}, 2672 \mathrm{~km}^{2}\right)$, has a population of approximately ten million, and spans elevations from sea level to the western slopes of the Andes mountain range (approximately $1.5 \mathrm{~km}$ asl) (Fig. 1).

The MALC experiences scarce rainfall, high atmospheric humidity, and persistent cloud cover due to strong subsidence inversion caused by the Southeastern Pacific anticyclone that prevails over the region for much of the year.

On the Peruvian coast, the predominant surface wind from the south-southwest favors the upwelling of cold waters along the coast, which, together with subsidence inversion of the subtropical anticyclone, results in dense cloud cover, particularly from June to November (cold period). In turn, weakening of the anticyclone during the warm period (December-May) increases the number of clear days. These conditions make the MALC one of the driest regions in the world. For example, during 2010-2015, average temperature was $23^{\circ} \mathrm{C}$ (range 13$32{ }^{\circ} \mathrm{C}$ ), average relative humidity was $85 \%$ (range $70-95 \%$ ), and average wind speed was $4 \mathrm{~m} / \mathrm{s}$ (range $1-5 \mathrm{~m} / \mathrm{s}$ ), predominantly from the south-southwest, with average annual rainfall of $10 \mathrm{~mm}$.

\section{Radiosonde observations at the international airport (1992-2014)}

In total, 3046 radiosondes were launched from the Jorge Chávez International Airport by the Peruvian Corporation of Commercial Airports and Aviation (CORPAC, for its acronym in Spanish) on a daily basis at 7:00 LT (in this paper, UTC-5 will be used as Local Time (LT)) to assess temperature, relative humidity, atmospheric pressure, and wind direction and speed as a function of height up to approximately $150 \mathrm{hPa}(15 \mathrm{~km})$ (Table 1).

\section{Daily radiosonde campaigns in Las Palmas}

To monitor the daily evolution of the marine boundary layer, two radiosonde campaigns were conducted in 2009 by SENAMHI. Radiosondes were launched from the Las Palmas meteorological station (Table 1) from February 16 to 28 during the warm period (33 launches) and from August 21 to 30 during the cold period ( 31 launches). Three launches were conducted each day, at 07:00, 13:00, and 19:00 LT, respectively.

Vertical profiles for meteorological variables (pressure, temperature, and relative humidity) were recorded by Vaisala RS92-SGP radiosondes. Calibration of the pressure, 
Fig. 1 Map of the metropolitan area of Lima-Callao. Red circles indicate air quality monitoring stations, black circles indicate the study stations, and red squares indicate radiosonde launch sites

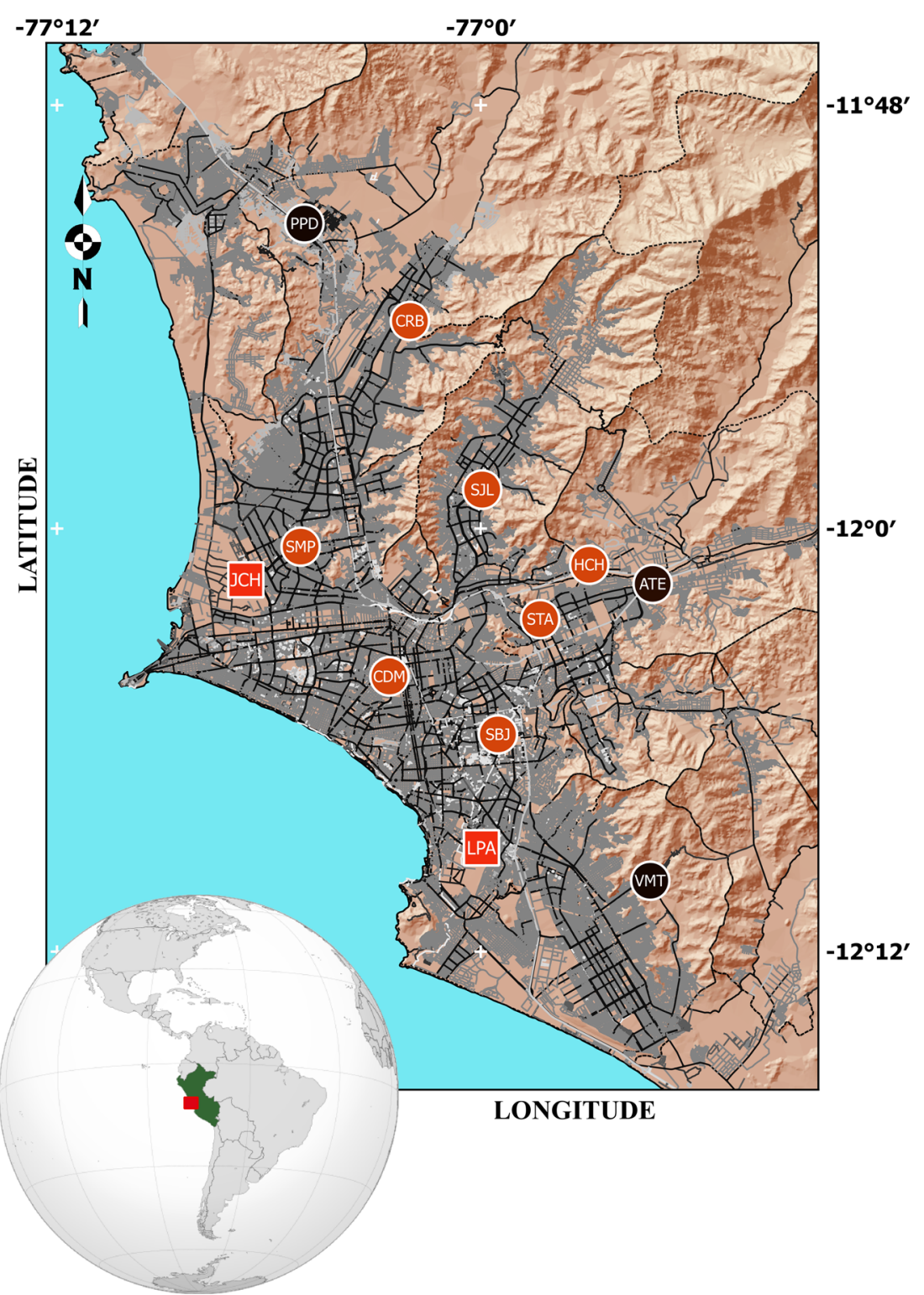

temperature, and humidity sensors was performed with the Vaisala Ground Check Set GC25.

\section{Analysis from sounding}

The potential temperature method (Theta method) was used to estimate the marine boundary layer height. This method finds the lowest critical inversion that meets the Theta gradient and lapse-rate criteria according to Heffter (1980). The two criteria are expressed as follows:

$\Delta \theta / \Delta \mathrm{Z}>0.5 \mathrm{~K} / 100 \mathrm{~m}^{-1}$

$\theta_{\mathrm{t}}-\theta_{\mathrm{b}}>2 \mathrm{~K}$

where $\Delta \theta / \Delta \mathrm{Z}$ is the potential temperature lapse rate in the inversion layer, and $\theta_{\mathrm{b}}$ and $\theta_{\mathrm{t}}$ refer to the potential temperatures at the base and top of the critical inversion layer, respectively.

\section{Surface observations $\left(\mathrm{O}_{3}, \mathrm{NO}, \mathrm{NO}_{2}\right.$, and $\left.\mathrm{CO}\right)$}

The hourly concentrations of $\mathrm{O}_{3}, \mathrm{NO}_{\mathrm{X}}$, and $\mathrm{CO}$ were measured using Teledyne analyzers (models 400E, T200, and T300, respectively; Teledyne Technologies, Inc., Thousand Oaks, CA, USA). The analyzer operation includes zero and span verifications, calibrations, detection of leaks, preventive maintenance, and documentation. Verifications are conducted on a monthly or weekly basis. The data are transmitted by telemetry to SENAMHI headquarters, where the data are validated after correcting null entries, duplicates, and/or anomalies. For further details, see Silva et al. (2017). 


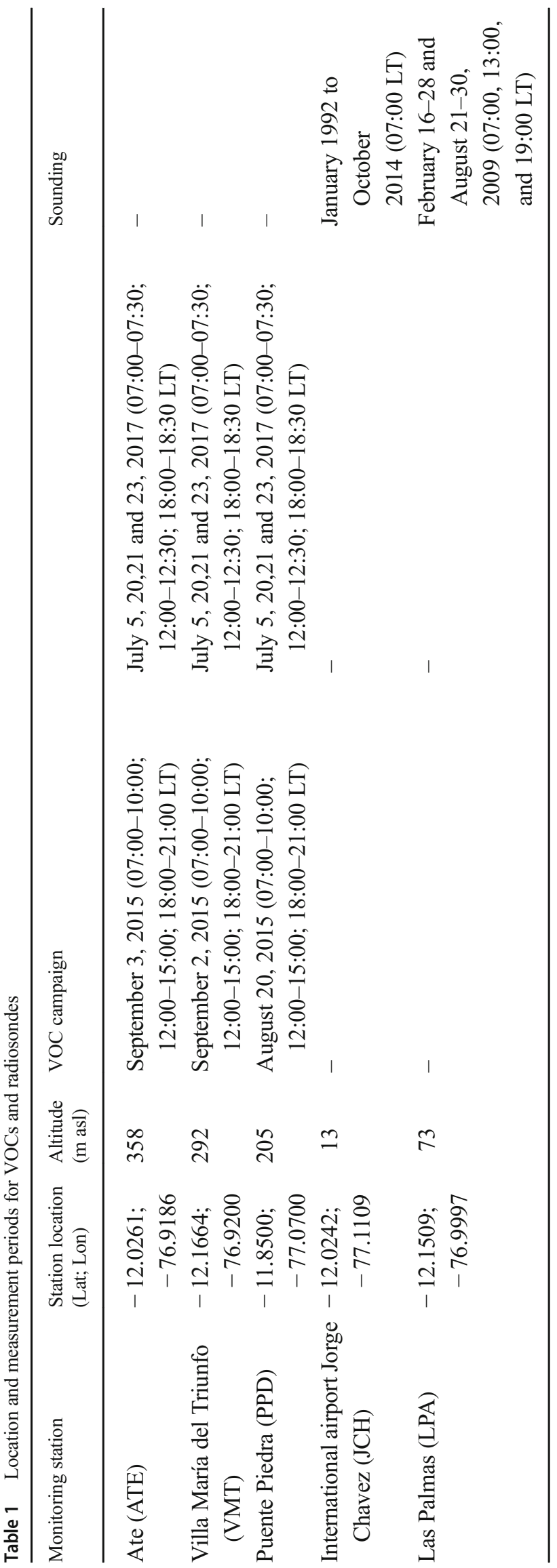

Due to the predominant wind direction and the significant contribution of mobile sources from downtown Lima, polluted air masses are transported to the northeast area of the city. Therefore, the selected air quality monitoring stations were ATE (Ate district), VMT (Villa María del Triunfo district), and PPD (Puente Piedra district), which are located $18 \mathrm{~km}$ east, $16 \mathrm{~km}$ south, and $22 \mathrm{~km}$ north of the center of the MALC, respectively (Fig. 1).

Descriptive statistical analyses of hourly measurements of $\mathrm{O}_{3}, \mathrm{NO}_{\mathrm{X}}, \mathrm{CO}$, and radiosonde data were performed using the $\mathrm{R}$ open-source statistical programming language ( $\mathrm{R}$ Development Core Team, Vienna, Austria) and its Openair package (Carslaw 2013) under the open-source software RStudio (RStudio Boston, MA, available from http:/www. rstudio.org/).

\section{Analysis of volatile organic compounds $\left(C_{6}-C_{12}\right)$}

During 2015 and 2017, two VOC $\mathrm{C}_{6}-\mathrm{C}_{12}$ campaigns were performed to complement the information collected from the air quality monitoring network (Table 1). The sampling sites were the same stations described previously (ATE, VMT, and PPD). The first exploratory campaign was performed three times per day. The second campaign was conducted on consecutive days and three times per day. The diurnal periods were selected to measure the levels associated with rush hours (7:00 and 18:00 LT) and favorable convective mixing conditions (13:00 LT).

Air was pulled by constant airflow $(0.1 \mathrm{~L} / \mathrm{min})$ and passed through cartridges packed with Tenax TA., Carboxen 1000, and Carbosieve SII. The $\mathrm{C}_{6}-\mathrm{C}_{12}$ species adsorbed on the cartridges were immediately analyzed in a gas chromatograph with a mass spectrometry detector (GC/MS) using the TO-1 method of the US Environmental Protection Agency (USEPA 1999).

The gas chromatograph mass spectrometer (Shimadzu, model GCMS-QP2010 ULTRA) includes a thermal desorption unit that volatilizes and pre-concentrates VOCs before injection into the GC. The system was calibrated using a mixture that contained $\mathrm{C}_{6}-\mathrm{C}_{12}$ compounds (carbon tetrachloride; benzene; toluene; ethylbenzene; o-xylene; m-xylene; $\mathrm{p}$ xylene; styrene; $n$-propylbenzene; naphthalene; $\mathrm{p}$ isopropyltoluene, purchased from SUPELCO). The estimated overall uncertainty of VOC measurements was approximately $10 \%$.

\section{Determination of priority volatile organic compounds $\left(C_{6}-C_{12}\right)$}

The measured mixing ratio for each $\mathrm{C}_{6}-\mathrm{C}_{12}$ species was multiplied by the maximum incremental reactivity (MIR) of the compounds (Carter 2010) to obtain their average reactivityadjusted mixing ratio. Thus, each $\mathrm{C}_{6}-\mathrm{C}_{12}$ species was 
categorized based on its proportional contribution to ozone formation according to the following formula:

Proportional weighting of the compound

$$
=(\mathrm{C}-\min ) \div(\max -\min ) \cdot 100
$$

where $\mathrm{C}$ is the average MIR-adjusted mixing ratio for the compound, and min (max) are the lowest (highest) average MIR-adjusted mixing ratios, respectively, for all compounds.

\section{Results and discussion}

\section{Weather patterns}

A 23-year climatology of vertical stability based on radiosondes launched from the Jorge Chavez International Airport at 7:00 LT is presented. The analysis identified two markedly different periods: June-November and DecemberMay.

The vertical temperature profiles obtained between June and November during 1992-2014 showed that the bases of the inversions frequently occurred between 0.6 and $0.9 \mathrm{~km}$ (max median 0.82 in June; min median 0.67 in September) (Fig. 2a), and that temperature increased between $2{ }^{\circ} \mathrm{C} / 100 \mathrm{~m}$ in August and $1.2^{\circ} \mathrm{C} / 100 \mathrm{~m}$ in November (Fig. 2b).

During this cold period (June-November), the strengthening and displacement of the subtropical anticyclone toward the central coast of South America intensifies the interaction between the Humboldt Current and the descending air masses. As a result, a thick layer of cold and humid air is generated in the lower troposphere. The above processes, coupled with radiational cooling from the top of the stratus cloud deck, leads to the development of a strong subsidence inversion (Albrecht 1981).

On the other hand, during the warm period (DecemberMay), the weakening of the subtropical anticyclone and displacement to higher latitudes produces clear skies over Lima that are occasionally interrupted by the passage of troughs.

The vertical temperature profiles obtained during December-May of 1992-2014 showed that radiative heating at surface level allows for the formation of weak surface inversions. The bases of the temperature inversions occurred between 0.1 and $0.6 \mathrm{~km}$ (max median 0.59 in December; min median 0.13 in March) (Fig. 2a), and the temperature increased between $1{ }^{\circ} \mathrm{C} / 100 \mathrm{~m}$ in May and $0.7^{\circ} \mathrm{C} / 100 \mathrm{~m}$ in January (Fig. 2b).

\section{Daily evolution of the marine boundary layer}

The strength and persistence of the subsidence inversion significantly determine the meteorological pattern over Lima. Accordingly, radiosonde campaigns for the two distinct periods (cold and warm) were designed to evaluate the daily marine boundary layer growth in more detail through vertical temperature profiles, potential temperature, water vapor, mixing ratios, wind speed, wind vectors, and cloud layers (Fig. 3).

\section{Cold period}

The lapse rate shows that, from August 23 to 29, the atmosphere experienced a significant temperature increase of approximately $9^{\circ} \mathrm{C}$ from a height of 0.6 to $2.0 \mathrm{~km}$ (Fig. 3a) as a result of adiabatic heating due to subsidence. Figure $3 \mathrm{c}$ shows the potential temperature gradient used to calculate the marine boundary layer height according to the method of Heffter (1980). The potential temperature isotherm of $295 \mathrm{~K}$ marked the height of the marine boundary layer.

During the period from August 21 to 30, 2009, the subsidence inversion base reached a maximum height of $1.1 \mathrm{~km}$ asl on August 21 (13:00 LT) and a minimum height of $0.46 \mathrm{~km}$ asl on August 26 (13:00 LT). The average subsidence
Fig. 2 Variation of the first temperature inversion base (a) and vertical temperature gradient (b) determined from radiosondes launched at the international airport by CORPAC during the period 1992-2014 at 07:00 LT. On each box, the central mark indicates the median, and the bottom and top edges of the box indicate the 25th and 75th percentiles, respectively. The whiskers extend to the minimum and maximum data points
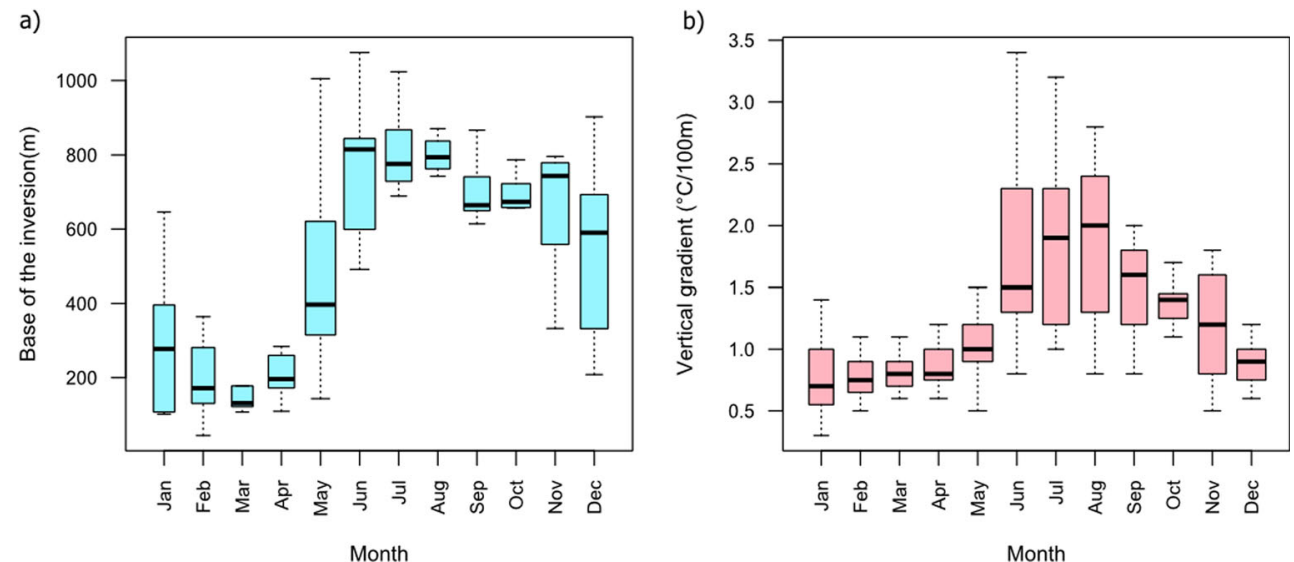

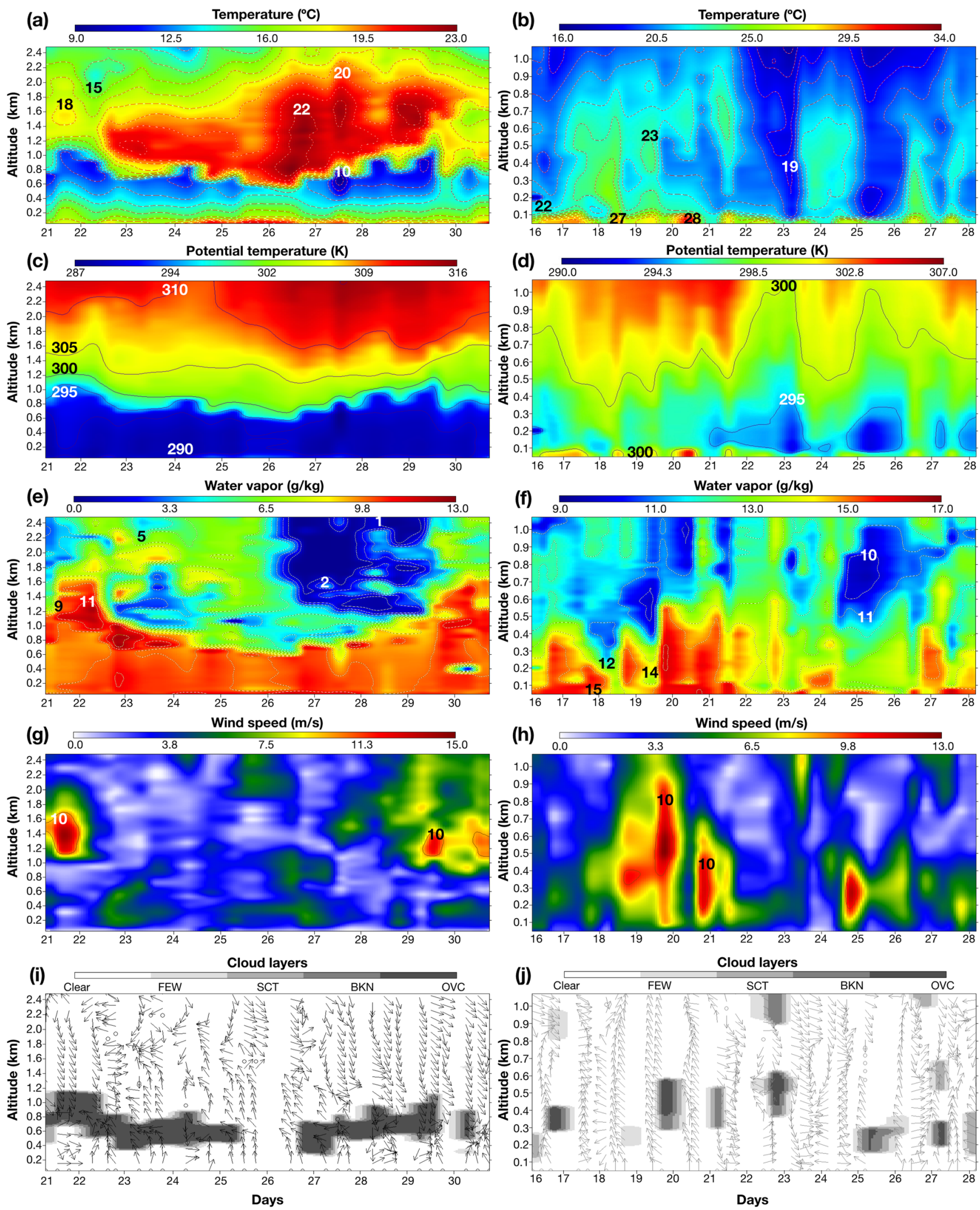

Fig. 3 Vertical profiles of temperature, potential temperature, water vapor, wind speed, and cloud layers measured using radiosondes launched from Las Palmas (Lima) during August 21-30 (right panel)

and February 16-28 (left panel) 2009. The cloud scale range considers clear sky (Clear), 1-2 oktas (FEW), 2-4 oktas (SCT: scattered), 5-7 oktas (BKN: broken), and 8 oktas (OVC: overcast) 
inversion height at 7:00, 13:00, and 19:00 LT showed low variability and was located at $798 \mathrm{~m}$ (standard deviation $(\mathrm{SD})=117), 796 \mathrm{~m}(\mathrm{SD}=207)$, and $677 \mathrm{~m}(\mathrm{SD}=154)$ asl, respectively. Under these meteorological conditions, no surface inversions were identified during the period August 21$30,2009$.

Figure $3 \mathrm{e}$ shows the high water-vapor content of the marine boundary layer, whereas the observed wind speeds were low, generally less than approximately $4 \mathrm{~m} / \mathrm{s}$ (Fig. $3 \mathrm{~g}$ ).

The period from August 21 to 30, 2009 was mostly characterized by cloudiness located below the subsidence inversion base. In general, a cloud layer with average thickness of $0.4 \mathrm{~km}$ was identified (Fig. 3i). Clear skies were observed only on August 26 and partly during the previous day.

\section{Warm period}

Analysis of the marine boundary layer from February 16 to 28, 2009 shows that the subsidence inversion was completely dissipated. By contrast, surface inversions were developed. Over this period, sunny days were occasionally interrupted by cloudiness, mainly during morning hours (7:00 LT).

The cross-section of temperature (Fig. 3b) shows that days with clouds (February 16, 21, 22, 25, 27, and 28) inhibit the formation of surface inversions. Conversely, clear days show the development of weak surface inversions. The most notable period was from February 17 to 19 , which showed a temperature inversion of approximately $3{ }^{\circ} \mathrm{C}$ with base ranging from 0.1 to $0.5 \mathrm{~km}$ asl.

Throughout the day, in general, the increase in surface heating increases the marine boundary layer height, thus improving vertical mixing conditions. During this period, the marine boundary layer grew throughout the day a few hundred meters. The average base of the thermal inversion at 7:00, 13:00, and 19:00 LT was located at $227 \mathrm{~m}(\mathrm{SD}=93), 350 \mathrm{~m}$ $(\mathrm{SD}=287)$, and $336 \mathrm{~m}(\mathrm{SD}=167)$ asl respectively.

Figure $3 \mathrm{f}$ shows maximum water vapor mixing ratio at the surface level, mainly on days with high surface temperatures. Those days show a significant increase in water vapor $(>15 \mathrm{~g} /$ $\mathrm{kg}$ ), with higher values than those recorded in winter. Furthermore, wind speed at the surface level is higher during summer than winter (Fig. 3j).

\section{Overview of $\mathrm{O}_{3}-\mathrm{NO}_{\mathbf{x}}-\mathrm{CO}$}

Lima shows high atmospheric concentrations of nitric oxide and carbon monoxide throughout the year, especially at the ATE station located downwind of the downtown area (Fig. 4). By contrast, ozone measurements exhibited low mixing ratios. For example, the annual average between 2015 and 2017 at the PPD station varied from 5.7 to $6.9 \mathrm{ppbv}$, and the mean diurnal cycle during the period did not exceed $18.9 \mathrm{ppbv}$ (13:00 LT). The 3-year average of the annual fourth-highest daily maximum 8-h average (MDA8) ozone-mixing ratio does not exceed $30.1 \mathrm{ppbv}$ (PPD). Similarly, annual maxima do not exceed 39 ppbv. Therefore, mixing ratios of surface $\mathrm{O}_{3}$ in the MALC comply with the national air quality standard of 51 ppbv.

During the warm period, the mean diurnal cycle at station ATE showed maximum nitric oxide concentration of $97 \mathrm{ppbv}$ at 7:00 LT, compared with 56 ppbv at 8:00 LT during the cold season (Fig. 5). This pattern of higher concentrations during the warm period was also observed at VMT (south of the city) and at PPD (north of the city).

$\mathrm{NO}$ and $\mathrm{CO}$ mixing ratios as a function of wind speed and direction are presented in polar coordinates in Fig. 6. The polar plot shows that in the warm period of 2017 , the mixing ratios of the primary gases $\mathrm{NO}$ and $\mathrm{CO}$ mostly overlap regarding wind direction and speed, as is expected for pollutants from the same source. Conversely, in the cold period, NO decreases and $\mathrm{CO}$ becomes concentrated (Fig. 5). Fine particles (PM 2.5) exhibited similar behavior than CO in ATE. The drastic decreases in nitric oxide compared to carbon monoxide from June to November (cold period) can be explained by differences in the lifetimes of these species under conditions of low atmospheric dispersion. Carbon monoxide has an average chemical lifetime of approximately 2 months in the troposphere while for $\mathrm{NO}_{\mathrm{x}}$ the lifetime is about 1 day (Yin et al. 2015; Wenig et al. 2003). Hence, it is hypothesized that subsidence inversion favor the accumulation of carbon monoxide throughout the cold period and the oxidation of $\mathrm{NO}_{\mathrm{x}}$ to gaseous $\mathrm{HNO}_{3}$, followed by its uptake into condensed phase would explain the significant drop of $\mathrm{NO}_{\mathrm{x}}$. As described in preceding sections, relative humidities are always high during the cold season, and precipitation in the form of a very light drizzle falls much of the time. For example, the relative humidity in ATE, VMT, and PPD varies between 81 and $88 \%$, between 88 and 95\%, and between 77 and $85 \%$ respectively during the cold period of 2016 .

\section{Ozone inhibition}

The mean diurnal cycle (Fig. 4) shows that the NO mixing ratio at ATE is always higher than 27.7 ppbv (14:00 LT), thereby preventing ozone accumulation during the day through titration with NO (reaction 1). The maximum ozone concentration of 19.3 ppbv reached at 13:00 LT is lower than the NO concentration at the same time (28.8 ppbv), which illustrates the strong inhibitory effect of NO.

$\mathrm{NO}+\mathrm{O}_{3} \rightarrow \mathrm{NO}_{2}+\mathrm{O}_{2} \quad($ Reaction $(1))$

The polar plot (Fig. 6) shows $\mathrm{O}_{3}$ response to $\mathrm{NO}$ levels. During the warm period, quadrants with higher ozone levels at ATE, PPD, and VMT are clearly accompanied by decreases in NO. Inversely, quadrants with low ozone levels have higher 
Fig. 4 Daily and weekly variations in $\mathrm{NO}_{2}, \mathrm{NO}, \mathrm{CO}$, and $\mathrm{O}_{3}$ mixing ratios for the period 2015-2017 $\left(\mathrm{O}_{3}\right.$ period: 2012 2017) at stations ATE, VMT, and PPD

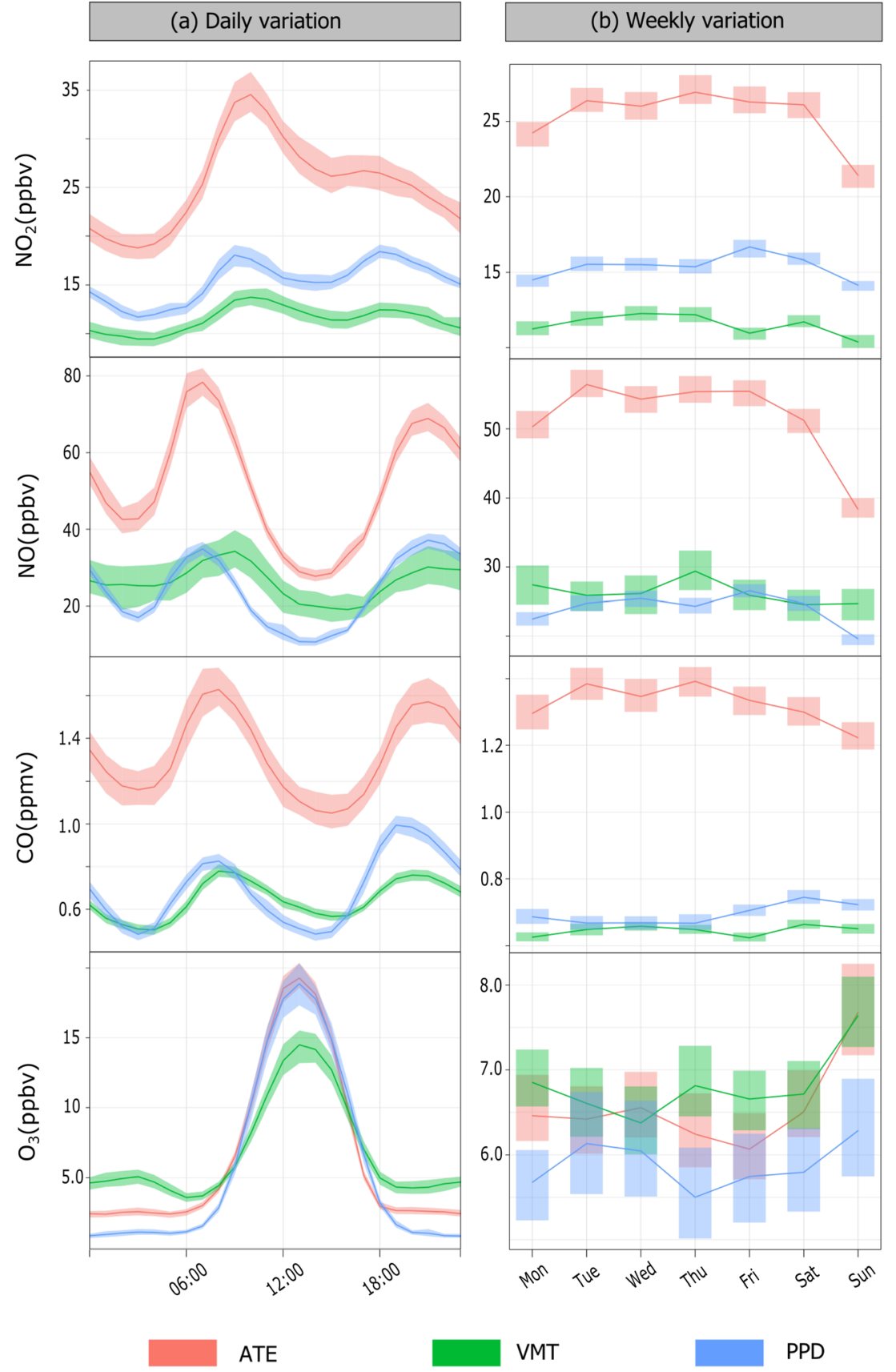

$\mathrm{NO}$ mixing ratios. This behavior is illustrated by the low $\mathrm{O}_{3} /$ NO ratio found in all sites especially in warm periods (Fig. 6).

The weekly variation of the primary pollutants $\mathrm{CO}$ and $\mathrm{NO}_{\mathrm{x}}$ (Fig. 4) shows that the main decrease affects nitric oxide, given the longer lifetime of $\mathrm{CO}$. Average mixing ratio indicates higher NO concentrations on workdays (MondayThursday) than at the weekend (Sunday), differing by 29, 9, and $19 \%$ at stations ATE, VMT, and PPD, respectively. Conversely, for ozone, the average mixing ratio is higher on the weekend (Sunday) than at the workdays (MondayThursday) differing by 16,13 , and $7 \%$, at the ATE, VMT, and PPD stations, respectively. Over the weekends, a decrease in $\mathrm{NO}_{\mathrm{x}}$ reduces consumption of the ${ }^{\circ} \mathrm{OH}$ radical (reaction 2). Consequently, the greater availability of ${ }^{\circ} \mathrm{OH}$ would favor VOC oxidation, leading to $\mathrm{O}_{3}$ formation. This result suggests a VOC-limited ozone-formation regime in the atmosphere of Lima.

$$
\mathrm{OH}+\mathrm{NO}_{2}+\mathrm{M} \rightarrow \mathrm{HNO}_{3}+\mathrm{M}
$$

$((\operatorname{Reaction}(2))$

The observed "weekend effect" highlights that future restrictions on nitrogen oxides without properly managing VOCs could lead to increased $\mathrm{O}_{3}$ concentrations, as described in the literature (Fujita et al. 2003). 
Fig. 5 Variations in $\mathrm{O}_{3}, \mathrm{NO}_{2}$, $\mathrm{NO}$, and $\mathrm{CO}$ mixing ratios and PM 2.5 concentration during the warm (left panel) and cold (right panel) periods of 2016 at stations ATE, VMT, and PPD

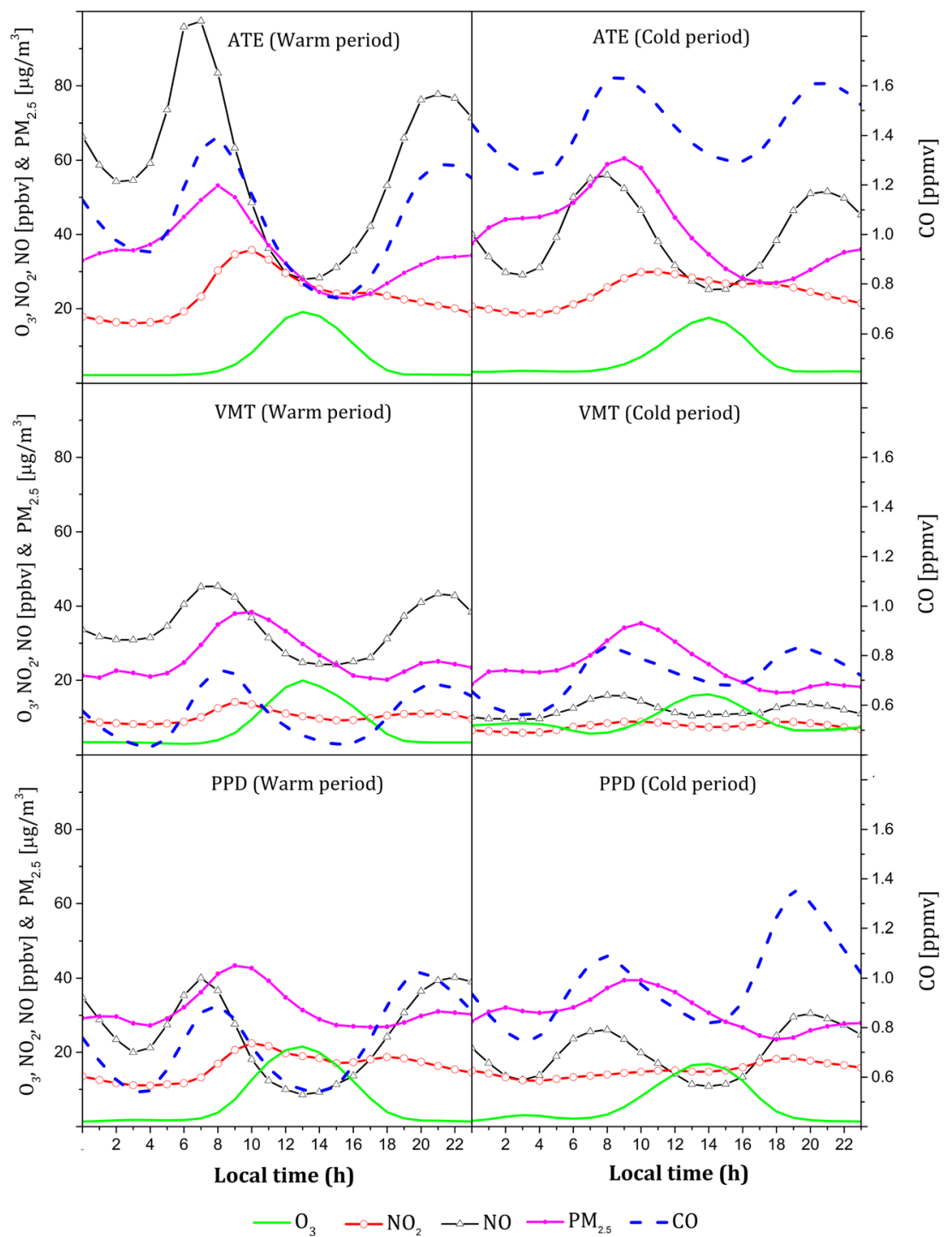

In summary, meteorological conditions of Lima do not promote photochemical activity during most of the year. The cloud cover affects actinic flux, and the moderate temperatures do not favor ozone formation. However, the highest ozone levels were typically found during the warm period mainly due to a presence of photochemical precursors and the occurrence of thermal inversions. Statistically significant differences between cold and warm periods (2014-2016) were found for all sites as determined by ANOVA $(\alpha=0.05)$.

From a chemical perspective, in Lima, NO is reacting rapidly with $\mathrm{O}_{3}$ to generate $\mathrm{NO}_{2}$ (reaction 1). Furthermore, at low VOC/NOx ratios, $\mathrm{OH}$ reacts predominantly with $\mathrm{NO}_{2}$ (reaction 2), removing radicals, retarding $\mathrm{O}_{3}$ formation, and providing (in theory) a major source of $\mathrm{HNO}_{3}$ in fogs and particles. Hence, the high degree of ozone inhibition caused by titration with nitric oxide, and the scarcity the radical ${ }^{\circ} \mathrm{OH}$ explain the lower ozone concentrations observed at the ATE, PPD, and VMT stations.

\section{Case study: VOCs in urban atmosphere of Lima}

The air quality network of the MALC fails to measure relevant organic precursors. Therefore, the campaigns conducted to measure $\mathrm{C}_{6}-\mathrm{C}_{12}$ species are the first efforts to address this issue in the MALC and results of $\mathrm{C}_{6}-\mathrm{C}_{12}$ speciation is presented to illustrate the impact of several VOCs on air quality and health. Specifically, knowledge of atmospheric VOC levels in the MALC is critical for (1) understanding the processes that govern ozone formation, (2) assessing their contribution to the formation of secondary organic aerosols, and (3) determining exposure to intrinsically hazardous substances.

\section{Pattern of $C_{6}-C_{12}$ species}

The results of $\mathrm{C}_{6}-\mathrm{C}_{12}$ species show that the highest mixing ratios are oriented eastward to the MALC center (ATE) in accordance with the predominant wind direction. Figure 7 


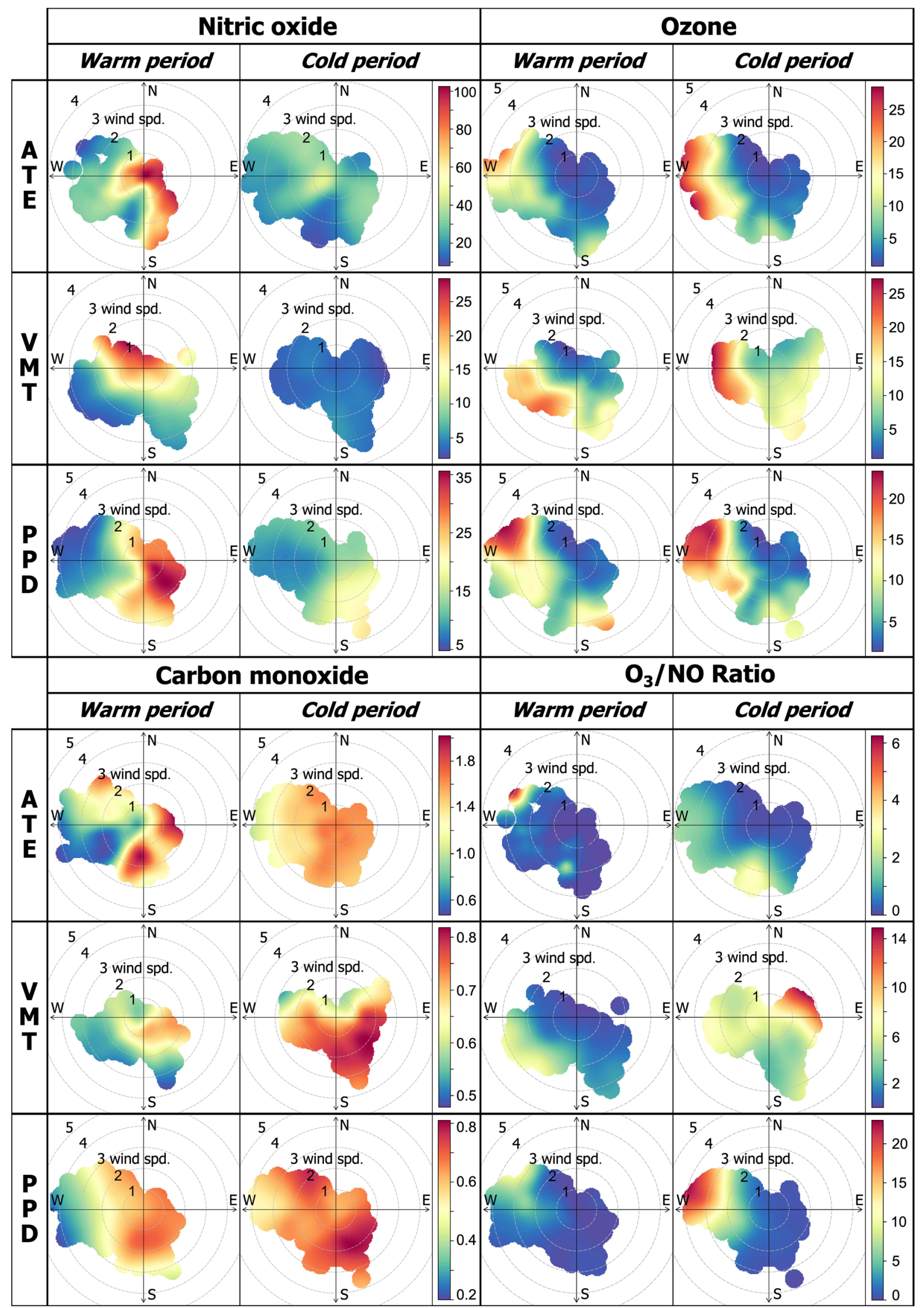

Fig. 6 Polar plot for: $\mathrm{NO}$ (ppbv), $\mathrm{O}_{3}$ (ppbv), $\mathrm{CO}$ (ppmv), and $\mathrm{O}_{3} / \mathrm{NO}$ ratio, during the warm and cold periods of 2017 at stations ATE, VMT, and PPD 
Fig. $7 \quad \mathrm{C}_{6}-\mathrm{C}_{12}$ pattern assessed at ATE, PPD, and VMT from exploratory campaigns performed on July 5, 20, 21, and 23, 2017 (top panel); comparison between the 2015 pattern and that assessed from the campaign conducted in July 2017 (bottom panel)
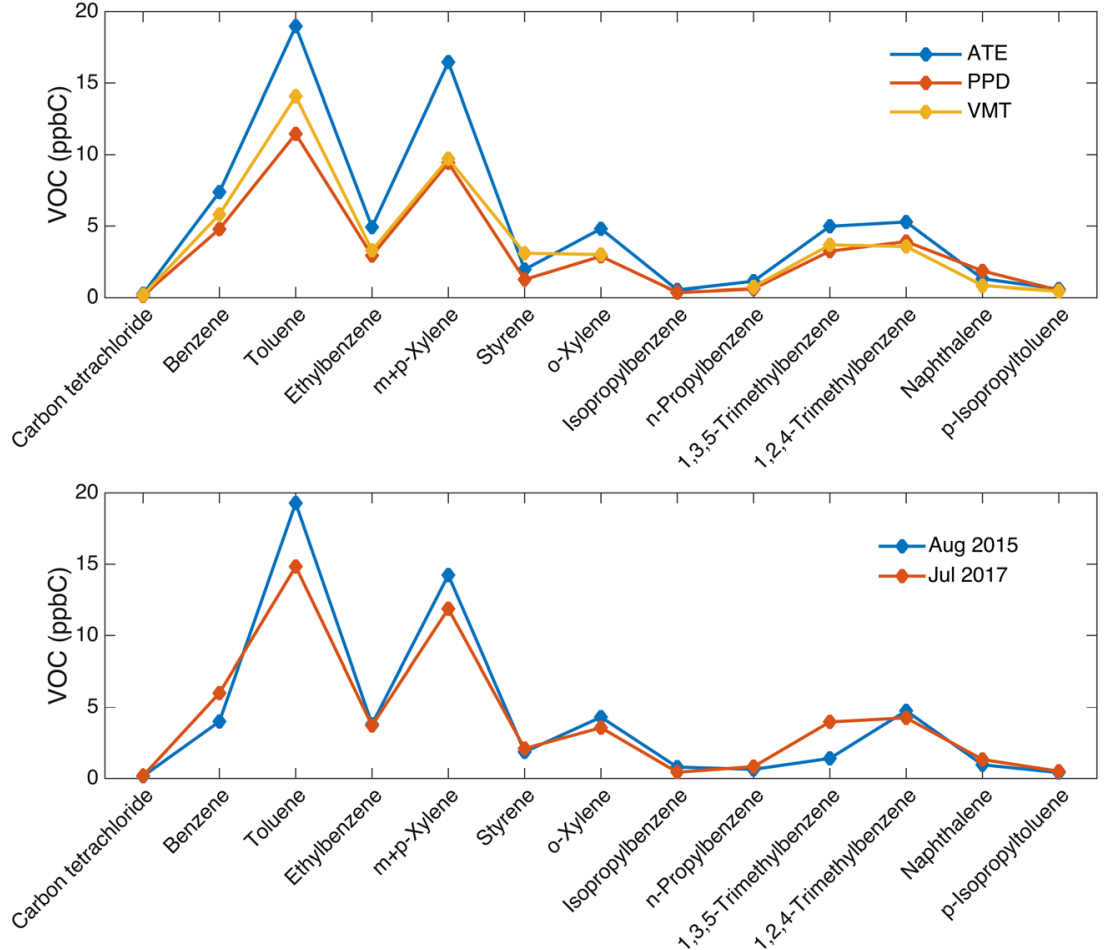

shows that the pattern of $\mathrm{C}_{6}-\mathrm{C}_{12}$ species analyzed at ATE, PPD, and VMT is relatively similar and comparable to campaigns conducted in August 2015 and July 2017 (Fig. 7). Consequently, the pattern of $\mathrm{C}_{6}-\mathrm{C}_{12}$ species confirms the contribution of a main source to the inventory of VOCs, whereas the speciation of $\mathrm{C}_{6}-\mathrm{C}_{12}$ compounds identifies tracers that are typical of vehicular emissions, e.g., benzene, toluene, and xylenes. The city of Lima, with approximately 2.2 million motor vehicles (Silva et al. 2017), experiences significant traffic congestion and gas emissions from vehicles throughout the day, due to the lack of a comprehensive public transport system (Tashiro and Taniyama 2002).

\section{Priority $\mathrm{C}_{6}-\mathrm{C}_{12}$ in Lima}

The importance of each compound for ozone formation was determined using the mixing ratios found in Lima (Table 2) and the maximum incremental reactivity (MIR) scale (Carter 2010). As shown in Table 2, adjusting the mixing ratio according to reactivity makes it possible to identify substances with greater potential to increase ozone formation, compared with those that are less productive despite having higher atmospheric concentrations. For example, benzene occurs at higher concentrations than o-xylene, but the latter has greater ozone-forming potential. At ATE, PPD, and VMT, the species with the highest ozone formation potential is the sum of the species m-xylene and p-xylene (expressed as a sum because these isomers cannot be separated by current analytical methods). As shown in Table 2, the theoretical productivity of ozone associated with $\mathrm{m}+\mathrm{p}$-xylene is 23,20 , and 17 times the productivity of benzene at ATE, PPD, and VMT, respectively. By contrast, the species naphthalene, styrene, $\mathrm{p}$ isopropyltoluene, $n$-propylbenzene, $n$-butylbenzene, and isopropilbenzene add little value in all sites.

Figure 8 shows the cumulative percentage of each $\mathrm{C}_{6}-\mathrm{C}_{12}$ species, based on reactivity (Eq. 3). Categorization shows that 5 of the 14 species account for nearly $90 \%$ of the ozone formation potential. These species are $\mathrm{m}+\mathrm{p}$-xylene $(36 \%)$, toluene $(21 \%), 1,2,4$-trimethylbenzene $(14 \%), 1,2,5$ trimethylbenzene $(13 \%)$, and o-xylene $(8 \%)$. Furthermore, these five VOCs prevail at the three sampling sites, and also match the priority compounds proposed by the USEPA.

\section{BTEX levels}

In 2014, the national ambient air quality standard for benzene was reduced from 1.3 to 0.63 ppbv annual average in Peru. Currently, no systematic benzene measurements are performed to evaluate compliance or exceedance of the standard. In this context, the campaigns reported herein determine the current levels of and exposure to this carcinogenic pollutant.

Elevated levels of reactive organic gases (BTEX: benzene, toluene, ethylbenzene, and xylene) have been found in the MALC. Table 3 shows that mean and median benzene concentrations exceeded the standard during the study period, with the maximum concentration $(1.2 \mathrm{ppbv})$ recorded at station ATE located east of Lima. For context, Table 3 also presents some statistical parameters gathered from BTEX 
Table 2 Mixing ratio of $\mathrm{C}_{6}-\mathrm{C}_{12}$ species at Lima multiplied by maximum incremental reactivity (MIR, Carter 2010)

\begin{tabular}{|c|c|c|c|c|c|c|c|c|c|c|c|c|c|}
\hline \multirow[t]{3}{*}{$\mathrm{C}_{6}-\mathrm{C}_{12}$} & \multicolumn{3}{|l|}{ Ate } & \multicolumn{3}{|l|}{ PP } & \multicolumn{3}{|l|}{ VMT } & \multirow[t]{3}{*}{$\operatorname{MIR}\left(\mathrm{g} \mathrm{O}_{3} / \mathrm{g}\right.$ VOC) } & \multicolumn{3}{|c|}{$\begin{array}{l}\text { Reactivity-adjusted } \\
\text { average mixing ratio }\end{array}$} \\
\hline & \multirow{2}{*}{$\begin{array}{l}\text { Median } \\
\text { ppbv }\end{array}$} & \multirow{2}{*}{ Mean } & \multirow{2}{*}{ Max } & \multirow{2}{*}{ Median } & \multirow{2}{*}{ Mean } & \multirow{2}{*}{ Max } & \multirow{2}{*}{ Median } & \multirow{2}{*}{ Mean } & \multirow{2}{*}{ Max } & & & & \\
\hline & & & & & & & & & & & Ate & PP & VMT \\
\hline $\mathrm{m}+\mathrm{p}$-Xylene & 1.4 & 2.1 & 7.4 & 0.98 & 1.2 & 4.7 & 0.97 & 1.2 & 2.3 & 9.75 & 20 & 11 & 12 \\
\hline Toluene & 2.3 & 2.7 & 9.1 & 1.2 & 1.6 & 5.3 & 1.2 & 2.0 & 4.9 & 4.0 & 11 & 6.5 & 8.0 \\
\hline 1,2,4-Trimethylbenzene & 0.30 & 0.59 & 3.1 & 0.35 & 0.43 & 1.3 & 0.27 & 0.40 & 0.84 & 11.97 & 7.0 & 5.2 & 4.7 \\
\hline 1,3,5-Trimethylbenzene & 0.30 & 0.55 & 2.8 & 0.28 & 0.36 & 1.1 & 0.30 & 0.41 & 0.95 & 11.76 & 6.5 & 4.2 & 4.8 \\
\hline o-Xylene & 0.35 & 0.60 & 2.5 & 0.30 & 0.36 & 1.2 & 0.47 & 0.38 & 0.64 & 7.64 & 4.6 & 2.7 & 2.9 \\
\hline Ethylbenzene & 0.46 & 0.62 & 2.1 & 0.29 & 0.37 & 1.2 & 0.41 & 0.41 & 0.75 & 3.04 & 1.9 & 1.1 & 1.3 \\
\hline Benzene & 0.81 & 1.2 & 4.8 & 0.77 & 0.80 & 1.8 & 1.0 & 0.97 & 1.3 & 0.72 & 0.9 & 0.6 & 0.7 \\
\hline Naphthalene & 0.07 & 0.13 & 0.53 & 0.06 & 0.19 & 1.1 & 0.06 & 0.08 & 0.14 & 3.34 & 0.4 & 0.6 & 0.3 \\
\hline Styrene & 0.22 & 0.24 & 0.53 & 0.13 & 0.16 & 0.50 & 0.13 & 0.39 & 1.5 & 1.73 & 0.4 & 0.3 & 0.7 \\
\hline p-Isopropyltoluene & 0.05 & 0.06 & 0.09 & 0.05 & 0.05 & 0.07 & 0.05 & 0.04 & 0.06 & 4.44 & 0.3 & 0.2 & 0.2 \\
\hline$n$-Propylbenzene & 0.10 & 0.13 & 0.36 & 0.05 & 0.07 & 0.17 & 0.08 & 0.08 & 0.16 & 2.03 & 0.3 & 0.1 & 0.2 \\
\hline$n$-Butylbenzene & 0.05 & 0.09 & 0.19 & 0.02 & 0.04 & 0.07 & - & - & - & 2.36 & 0.2 & 0.1 & 0.0 \\
\hline Isopropylbenzene & 0.06 & 0.06 & 0.09 & 0.04 & 0.04 & 0.05 & - & - & - & 2.52 & 0.1 & 0.1 & 0.0 \\
\hline
\end{tabular}

measurements in Lima and compares them to the latest official values reported for Santiago de Chile (SCL), another South American capital city, which has been designated an ozone non-attainment area over the last 20 years (Seguel et al. 2018).

The mean benzene values found in the MALC exceed those reported for downtown SCL and approximately $16 \mathrm{~km}$ downwind. In Table 3, upwind SCL is a suburban site located $26 \mathrm{~km}$ from the city center. Mean toluene concentrations are similar for both cities, and the maximum toluene concentrations were found in ATE and in downtown SCL. Mean ethylbenzene concentrations are relatively similar for both cities, except for higher mean concentrations in central SCL.
As mentioned in the previous section, m-xylene and pxylene are the species with the highest ozone formation potential among the $\mathrm{C}_{6}-\mathrm{C}_{12}$ species studied in the MALC, similar to the SCL, considering the 54 PAMS. The levels of $\mathrm{m}+$ p-xylene at ATE are similar to those found downwind of SCL. The same was observed for mean o-xylene levels. Nevertheless, the ozone standard is not exceeded at ATE, in contrast to downwind SCL. This result is attributed to the prevailing meteorological conditions in Lima and to the chemical regime characterized by the ozone reaction with $\mathrm{NO}$ and low availability of the radical ${ }^{\circ} \mathrm{OH}$ consumed by high levels of $\mathrm{NO}_{\mathrm{x}}$ relative to VOCs.
Fig. 8 Cumulative sum of the proportional weight of each $\mathrm{C}_{6}-\mathrm{C}_{12}$ compound. The red line represents the cut point of $90 \%$

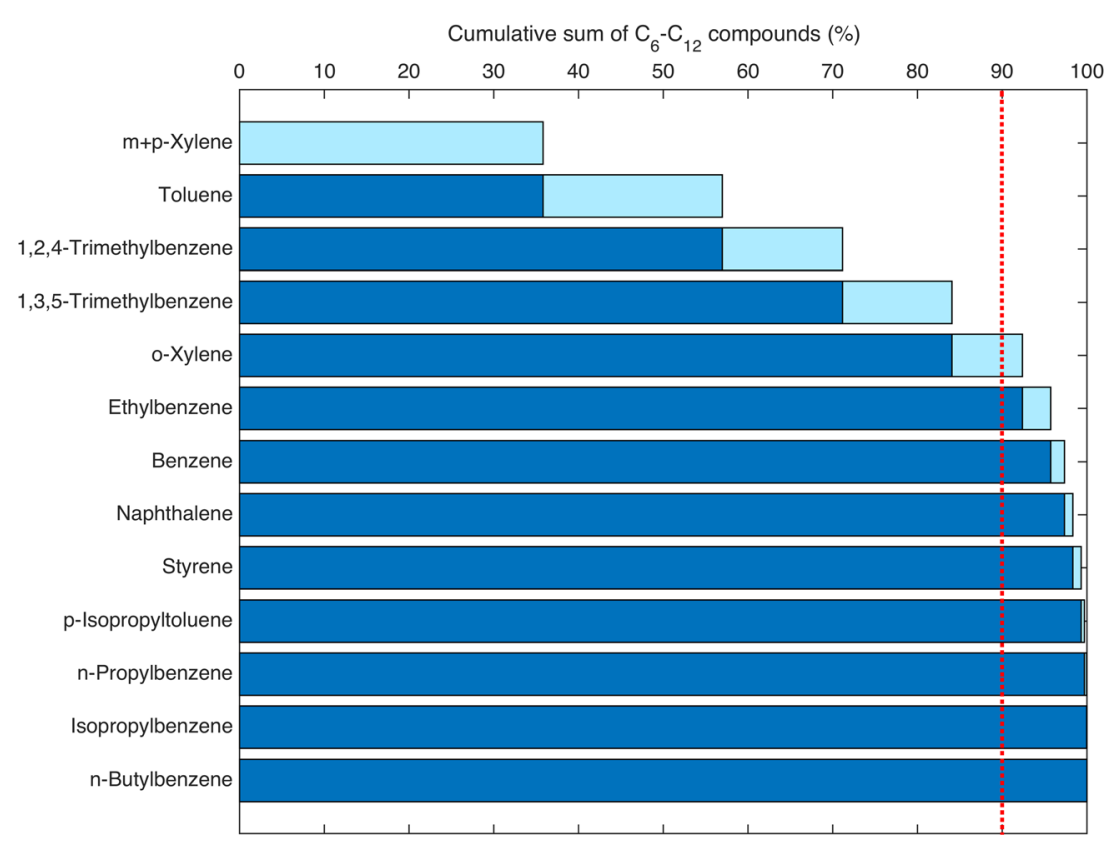




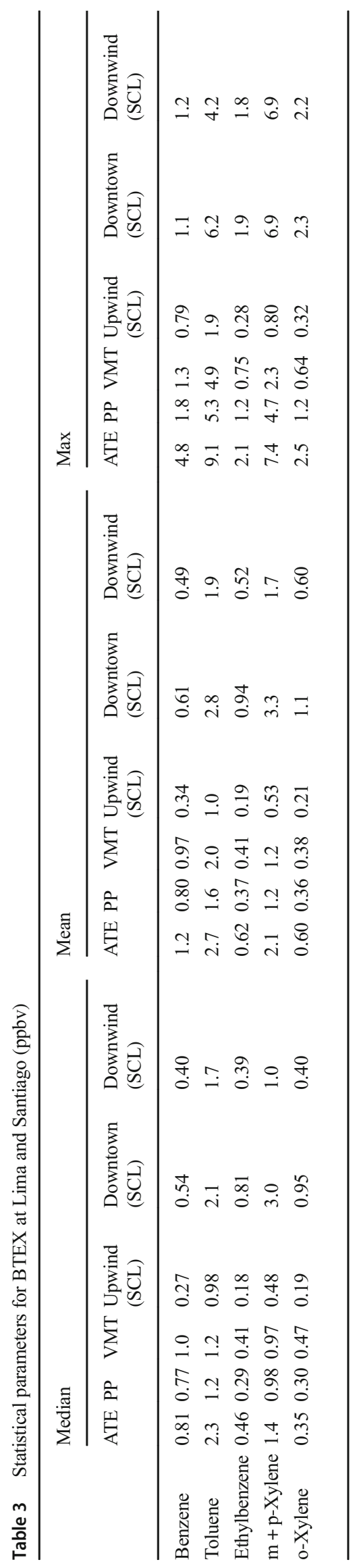


Table 4 Comparison of mean values for aromatic hydrocarbon mixing ratios for various cities of Latin America (Sao Paulo: Alvim et al. 2017; Santiago: Seguel et al. 2013; Mexico City: JaimesPalomera et al. 2016)

\begin{tabular}{llllll}
\hline Sites & $\begin{array}{l}\text { Benzene } \\
\text { ppbv }\end{array}$ & Toluene & Ethylbenzene & $\mathrm{m}+\mathrm{p}$-Xylene & o-Xylene \\
\hline $\begin{array}{l}\text { Sao Paulo } \\
\quad 2008\end{array}$ & $0.81 \pm 0.02$ & $4.40 \pm 0.18$ & $1.15 \pm 0.03$ & $0.65 \pm 0.03 / 1.40 \pm 0.13$ & $0.63 \pm 0.01$ \\
$\begin{array}{l}\text { Santiago } \\
\quad 2009\end{array}$ & $0.48 \pm 0.13$ & $1.9 \pm 0.9$ & $0.55 \pm 0.38$ & $1.9 \pm 1.4$ & $0.64 \pm 0.45$ \\
$\begin{array}{l}\text { Mexico City } \\
\quad 2012\end{array}$ & $1.63 \pm 0.42$ & $8.99 \pm 5.18$ & $0.82 \pm 0.45$ & $1.42 \pm 0.58$ & $1.09 \pm 0.58$ \\
$\begin{array}{l}\text { Lima } \\
2017\end{array}$ & $1.0 \pm 0.2$ & $2.1 \pm 0.5$ & $0.46 \pm 0.13$ & $1.5 \pm 0.5$ & $0.45 \pm 0.14$ \\
\hline
\end{tabular}

For Sao Paulo, separate results for m-xylene and $\mathrm{p}$-xylene were available
Lastly, Table 4 compares BTEX levels with other two Latin America megacities (Sao Paulo and Mexico City). In general, a good agreement for $\mathrm{m}+\mathrm{p}$-xylenes and o-xylene is observed. Toluene stands out as one of the aromatics that presents higher concentrations and greater variation among the four cities reported.

\section{Risk assessment for benzene}

Benzene is a known carcinogen (WHO 2000). Therefore, the USEPA and WHO have established ranges and levels of risk associated with its inhalation of $2.2 \cdot 10^{-6}-7.8 \cdot 10^{-6}$ and $6 \cdot 10^{-6}$, respectively (ATSDR 2007). Benzene measurements at ATE, PPD, and VMT were used to estimate the excess lifetime risk of leukemia. Table 5 shows the exposure concentration modeled for a residential scenario. This concentration was calculated by multiplying the $95 \%$ upper confidence limit (95\% UCL) of the arithmetic mean by the factor 0.41 , which corresponds to a residential scenario. Specifically, an average lifetime of 70 years, exposure duration of 30 years, and an exposure frequency of 350 days/year were considered to determine this factor (Table 5).

The results show that the cancer risk ranges from 2 per hundred thousand to 9 per million inhabitants. The estimated risk associated with benzene inhalation is considered acceptable, according to the criteria established by the USEPA and WHO.

\section{Conclusions}

Twenty-three years of radiosonde observations identified a persistent subsidence inversion over Lima, which was strongest during cold period (June-November) with an average base altitude of $0.74 \mathrm{~km}$. During the warm period (December-May), the subsidence inversion was dissipated entirely, and weak surface inversions developed with an average base altitude of $0.29 \mathrm{~km}$.

The daily evolution of the marine boundary layer showed no surface inversions during the period August 21-30, 2009 and a cloud layer with an average thickness of $0.4 \mathrm{~km}$ was usually identified below the subsidence inversion base. During February 16-28, 2009, the marine boundary layer grew along the day reaching the higher average altitude of $0.35(\mathrm{SD}=0.29)$ at 13:00 LT.

In the warm period, efficient ozone formation was hindered by the intermittent occurrence of numerous cloudy days. Similarly, on clear days with greater solar radiation and with the presence of precursors, a substantial increase in ozone was not observed, which was again attributed to strong inhibitory effect resulting from the titration of nitric oxide that is present at high atmospheric concentrations in the Lima-Callao metropolitan area. Maintaining compliance with ozone standards over time, in a continuously growing city, will require effective measures for the balanced reduction of both $\mathrm{NO}_{\mathrm{x}}$ and VOC concentrations.

Table 5 Exposure levels and risk assessment for benzene according to EPA and WHO inhalation unit risk

\begin{tabular}{|c|c|c|c|c|c|c|c|c|c|c|c|c|}
\hline \multirow[t]{3}{*}{ Site } & \multirow[t]{3}{*}{$\mathrm{N}^{\circ}$} & \multirow{3}{*}{$\begin{array}{l}\text { Min. } \\
\mu \mathrm{g} / \mathrm{m}\end{array}$} & \multirow[t]{3}{*}{ Max. } & \multirow[t]{3}{*}{$\mathrm{SD}$} & \multirow{3}{*}{$\begin{array}{l}\text { Coefficient of } \\
\text { variation }\end{array}$} & \multirow[t]{3}{*}{ Mean } & \multirow[t]{3}{*}{ Median } & \multirow[t]{3}{*}{$95 \%$ Student's $t$ UCL } & \multirow{3}{*}{$\begin{array}{l}\text { Residential } \\
\text { exposure } \\
\text { a(Factor: } 0.41 \text { ) }\end{array}$} & \multicolumn{3}{|c|}{ Inhalation unit risk } \\
\hline & & & & & & & & & & \multicolumn{2}{|c|}{ USEPA range } & \multirow{2}{*}{$\begin{array}{l}\text { WHO } \\
6.0 \cdot 10^{-6}\end{array}$} \\
\hline & & & & & & & & & & $2.2 \cdot 10^{-6}$ & $7.8 \cdot 10^{-6}$ & \\
\hline ATE & 12 & 0.25 & 15 & 4.4 & 3.6 & 3.9 & 2.6 & 6.3 & 2.6 & 6 in $1 \cdot 10^{6}$ & 2 in $1 \cdot 10^{5}$ & 2 in $1 \cdot 10^{5}$ \\
\hline PPD & 12 & 0.81 & 5.6 & 1.5 & 1.9 & 2.5 & 2.5 & 3.5 & 1.4 & 3 in $1 \cdot 10^{6}$ & 1 in $1 \cdot 10^{5}$ & 9 in $1 \cdot 10^{6}$ \\
\hline VMT & 12 & 1.7 & 4.3 & 1.1 & 1.1 & 3.1 & 3.3 & 3.8 & 1.5 & 3 in $1 \cdot 10^{6}$ & 1 in $1 \cdot 10^{5}$ & 9 in $1 \cdot 10^{6}$ \\
\hline
\end{tabular}

${ }^{\mathrm{a}}$ Factor $=(350 \times 30) /(70 \times 365)$ : average lifetime $=70$ years; exposure duration $=30$ years; exposure frequency $=350$ days $/$ year 
The pattern of $\mathrm{C}_{6}-\mathrm{C}_{12}$ species was relatively similar in the atmosphere of the Lima-Callao metropolitan area and was mainly attributed to mobile sources. In the group of $\mathrm{C}_{6}-\mathrm{C}_{12}$ species, five were classified as priority species for their ozoneforming potential: $\mathrm{m}+\mathrm{p}$-xylene, toluene, 1,2,4trimethylbenzene, 1,2,5-trimethylbenzene, and o-xylene. Further, the observed BTEX levels were high and similar to those reported in non-attainment areas (benzene (1.0 ppbv), toluene $(2.1 \mathrm{ppbv})$, ethylbenzene $(0.5 \mathrm{ppbv}), \mathrm{m}+\mathrm{p}$-xylene (1.5 ppbv), and o-xylene (0.4 ppbv)).

In terms of public health implications, the exploratory benzene mixing ratios found in this study exceeded the standard of 0.61 ppbv. However, exposure to this carcinogenic pollutant is considered acceptable, based on risk analysis conducted in accordance with USEPA and WHO guidelines.

Acknowledgements Rodrigo Seguel acknowledges support from CONICYT, FONDECYT Program, initiation into research 2013, Project No 11130177.

Funding This work has been funded by the SNIP project: expansion and improvement of the monitoring network for air quality forecasting in Metropolitan Lima ( $\left.{ }^{\circ} 199842\right)$

\section{References}

Albrecht JA (1981) The twenty year average atmospheric structure at Lima, Peru. Dissertation. Dept. of Meteorology, Florida State University, Tallahassee

Alvim DS et al (2017) Main ozone-forming VOCs in the city of Sao Paulo: observations, modelling and impacts. Air Qual Atmos Health 10:421-435. https://doi.org/10.1007/s11869-016-0429-9

ATSDR (Agency for Toxic Substances and Disease Registry) (2007) Toxicological profile for benzene. Update. Public Health Service, U.S. Department of Health and Human Services, Atlanta, GA

Bell ML, McDermott A, Zeger SL, Samet JM, Dominici F (2004) Ozone and short-term mortality in 95 us urban communities, 1987-2000. JAMA 292:2372-2378. https://doi.org/10.1001/jama.292.19.2372

Carslaw DC (2013) The Openair manual: open-source tools for analyzing air pollution data. Manual for version 0.9. King's College London. London, UK. [WWW Document] URL https://goo.gl/iigCI9 (accessed 5 January 2018)

Carter WPL (2010) Development of the SAPRC-07 chemical mechanism. Atmos Environ 44:5324-5335. https://doi.org/10.1016/j. atmosenv.2010.01.026

Chameides W, Lindsay R, Richardson J, Kiang C (1988) The role of biogenic hydrocarbons in urban photochemical smog: Atlanta as a case study. Science 241:1473-1475. https://doi.org/10.1126/ science. 3420404

Enfield DB (1981) Thermally driven wind variability in the planetary boundary layer above Lima, Peru. J Geophysical Res: Oceans 86: 2005-2016. https://doi.org/10.1029/JC086iC03p02005

Fiore AM, Naik V, Leibensperger EM (2015) Air quality and climate connections. J Air Waste Manage Assoc 65:645-685. https://doi. org/10.1080/10962247.2015.1040526

Forouzanfar MH et al (2015) Global, regional, and national comparative risk assessment of 79 behavioural, environmental and occupational, and metabolic risks or clusters of risks in 188 countries, 1990-2013: a systematic analysis for the global burden of disease study 2013 . Lancet 386:2287-2323

Fujita EM, Campbell DE, Stockwell WR, Lawson DR (2012) Past and future ozone trends in California's south coast air basin: reconciliation of ambient measurements with past and projected emission inventories. J Air Waste Manage Assoc 63:54-69. https://doi.org/ 10.1080/10962247.2012.735211

Fujita EM, Stockwell WR, Campbell DE, Keislar RE, Lawson DR (2003) Evolution of the magnitude and spatial extent of the weekend ozone effect in California's south coast air basin, 1981-2000. J Air Waste Manage Assoc 53:802-815. https://doi.org/10.1080/10473289. 2003.10466225

Heffter JL (1980) Transport layer depth calculations. Second Joint Conference on Applications of Air Pollution Meteorology. New Orleans, LA

Jaimes-Palomera M, Retama A, Elias-Castro G, Neria-Hernández A, Rivera-Hernández O, Velasco E (2016) Non-methane hydrocarbons in the atmosphere of Mexico City: Results of the 2012 ozone-season campaign. Atmos Environ 132:258-275. https://doi.org/10.1016/j. atmosenv.2016.02.047

Lippmann M (1991) Health effects of tropospheric ozone. Environ Sci Technol 25:1954-1962. https://doi.org/10.1021/es00024a001

Liu JC, Peng RD (2018) Health effect of mixtures of ozone, nitrogen dioxide, and fine particulates in 85 US counties. Air Qual Atmos Health 11:311-324. https://doi.org/10.1007/s11869-017-0544-2

MINAM (2017) Decreto supremo N 003-2017-MINAM-Estandares Nacionales de calidad ambiental (ECA) para aire, Ministerio del Ambiente (MINAM). Republic of Peru. [WWW Document] doi: D.SNo 003-2017-MINAM

Monks PS et al (2015) Tropospheric ozone and its precursors from the urban to the global scale from air quality to short-lived climate forcer. Atmos Chem Phys 15:8889-8973. https://doi.org/10.5194/ acp-15-8889-2015

Rappengluck B et al (2005) An urban photochemistry study in Santiago de Chile. Atmos Environ 39:2913-2931. https://doi.org/10.1016/j. atmosenv.2004.12.049

Schultz MG et al (2017) Tropospheric ozone assessment report: database and metrics data of global surface ozone observations. Elem Sci Anth 5:58. https://doi.org/10.1525/elementa.244

Seguel RJ, Mancilla CA, MAL G (2018) Stratospheric ozone intrusions during the passage of cold fronts over central Chile. Air Qual Atmos Health:1-14 11:535-548. https://doi.org/10.1007/s11869-0180558-4

Seguel RJ, Mancilla CA, Rondanelli R, Leiva MA, Morales RGE (2013) Ozone distribution in the lower troposphere over complex terrain in Central Chile. J Geophys Res Atmos 118:2966-2980. https://doi. org/10.1002/jgrd.50293

Seguel RJ, Morales SR, Leiva GM (2012) Ozone weekend effect in Santiago, Chile. Environ Pollut 162:72-79. https://doi.org/10. 1016/j.envpol.2011.10.019

Silva J, Rojas J, Norabuena M, Molina C, Toro RA, Leiva-Guzmán MA (2017) Particulate matter levels in a south American megacity: the metropolitan area of Lima-Callao, Peru. Environ Monit Assess 189: 635. https://doi.org/10.1007/s10661-017-6327-2

Tashiro Y, Taniyama T (2002) Atmospheric NO2 and CO concentration in Lima, Peru. Environ Int 28:227-233. https://doi.org/10.1016/ S0160-4120(02)00018-1

Toro R, Donoso C, Seguel RJ, Morales RES, Leiva MG (2013) Photochemical ozone pollution in the Valparaiso region, Chile. Air Qual Atmos Health 7:1-11. https://doi.org/10.1007/s11869-0130218-7

Toro R, Seguel RJ, Morales SRE, Leiva GM (2014) Ozone, nitrogen oxides, and volatile organic compounds in a central zone of Chile. Air Qual Atmos Health 8:1-13. https://doi.org/10.1007/s11869014-0306-3 
Underhill LJ et al (2015) Association of roadway proximity with indoor air pollution in a peri-urban community in Lima, Peru. Int $\mathrm{J}$ Environ Res Public Health 12:13466-13481. https://doi.org/10.3390/ ijerph121013466

USEPA (1999) Method TO-1: method for the determination of volatile organic compounds (VOCs) in ambient air using Tenax adsorption and gas chromatography/mass spectrometry $(\mathrm{GC} /$ $\mathrm{MS}$ ), in: Compendium of Methods for the Determination of Toxic Organic Compounds in Ambient Air, second ed. EPA/ 625/R-96/010b. Office of Research and Development, U.S. Environmental Protection Agency
USEPA (2017) Final revised PAMS VOC target list. https://www3.epa. gov/ttnamti1/files/ambient/pams/targetlist.pdf

Wenig M, Spichtinger N, Stohl A, Held G, Beirle S, Wagner T, Jähne B, Platt U (2003) Intercontinental transport of nitrogen oxide pollution plumes. Atmos Chem Phys 3:387-393

WHO (2000) Air Quality Guidelines for Europe 2000, second ed. Copenhagen, World Health Organization Regional Office for Europe. http://www.euro.who.int/ data/asset s/pdf file/0005/ 74732/E71922.pdf

Yin Y, Chevallier F, Ciais P, Broquet G, Fortems-Cheiney A, Pison I, Saunois M (2015) Decadal trends in global CO emissions as seen by MOPITT. Atmos Chem Phys 15:13433-13451. https://doi.org/ 10.5194/acp-15-13433-2015 